\title{
Turbulence in the Currency Markets_-What Does It Mean for International Business?
}

\author{
Robert N. Mefford, University of San Francisco, USA
}

In 2014 global currency markets erupted with volatility not seen since the 2008 global recession. The US dollar (USD) strengthened against the euro and yen, and many emerging market currencies plummeted. Then in January 2015 the Swiss central bank removed its ceiling on the Swiss Franc and it rose $30 \%$ in one day against the euro. Throughout 2015 the USD continued to strengthen against other major currencies. However, in early 2016 the USD fell against these same currencies. The Chinese yuan, in contrast, strengthened relentlessly against the USD until mid-2015 when the Chinese government engineered devaluation, and it has since fallen $7 \%$ as of late 2017. In June 2016, Britain's vote to leave the EU created another bout of extreme volatility, with the pound falling $10 \%$ against the USD within a few days. After Donald Trump was elected President of the U.S., the USD gained 3\% against a basket of currencies within a month. These trends and reversals have caused great volatility in the interbank forex market (FX), which historically was less than $20 \%$ a year for major currencies but now some experience this in a week. This volatility is good for currency traders and speculators, but what does it mean for managers of multinational enterprises (MNEs)? This article explores how currency volatility affects many aspects of business including strategy, investment and finance, operations and sourcing, marketing, and risk management as well as strategies to mitigate, or even benefit from it.

\section{Why Has Volatility Increased in the Forex Markets?}

Figure 1 shows how FX volatility has increased for 23 currency pairs since 2012, with volatility falling through 2012, spiking in 2013, falling in 2014, and rising to high levels again in 2015 and into 2016. Through October of 2017, FX volatility has fallen but remains above the low levels of 2014. Volatility is 3 -month option implied volatility for 23 USD-based currency pairs including both developed country and emerging market currencies.

A confluence of factors drove this heightened volatility in currency markets. First, the euro and yen have long been considered overvalued on a purchasing power parity basis. To many economists adjustment was inevitable. However, currencies

Figure 1. JPMorgan Global FX Volatility Index (source: Bloomberg)

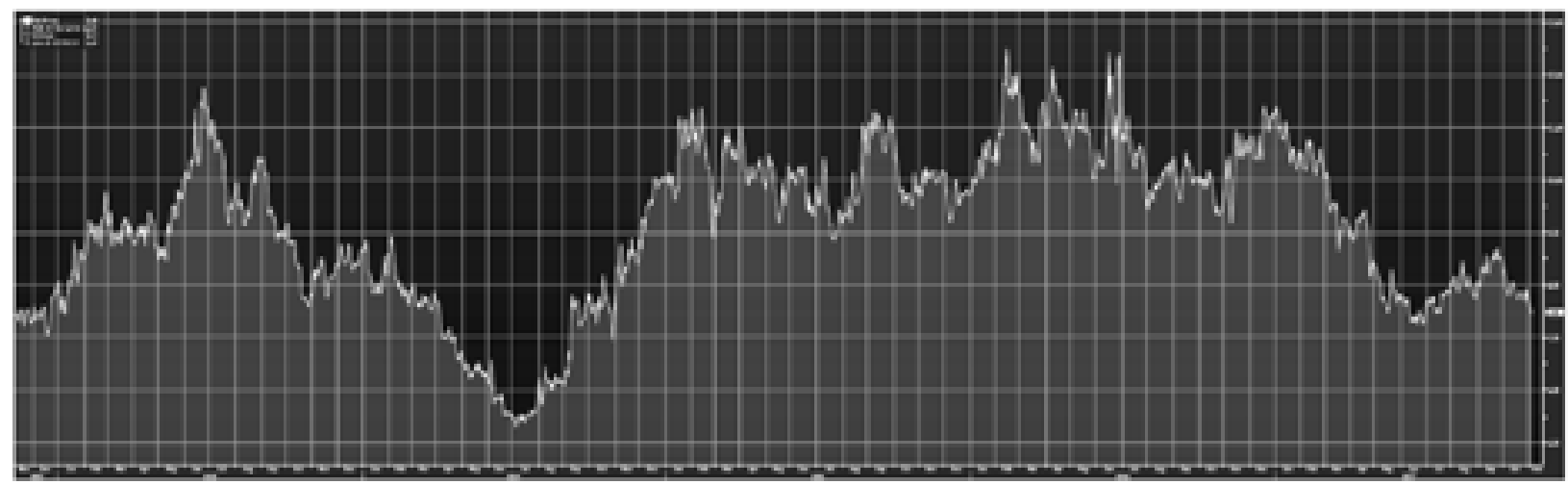


seem to go through cycles of over and undervaluation that may persist for years (Rogoff, 1996). So what triggered adjustment in 2014? There appear to be several factors.

In 2013 the Japanese government initiated a program of quantitative easing $(\mathrm{QE})$ to boost its sluggish economy by lowering the value of the yen to boost exports. The yen soon began a gradual and persistent decline. QE expanded money supply and lowered interest rates, which contributed to the yen's decline. Currency traders accepted these devaluation efforts, thus building momentum for further declines. Witnessing successful QE in Japan and the US, the European Central Bank (ECB) launched its own QE program in early 2015, and just its announcement precipitated a rapid decline of the euro.

Meanwhile, faster GDP growth, falling unemployment, and increased consumption in the U.S. encouraged the Federal Reserve to end its QE program in October 2014 and hint that it would begin raising interest rates in 2015. It did not actually begin raising rates until 2016, and further rate increases are expected through 2017 into 2018. In 2016, U.S. interest rates were higher compared to Europe and Japan, and the prospect of the difference widening created demand for US fixed income investments and boosted the USD. Concurrently, appreciating U.S. equity markets and real estate created investment demand for USD. Divergent monetary policy and economic growth between the US and Europe and Japan contributed to uncertainty about future global economic prospects. Also, the unconventional nature of $\mathrm{QE}$, and its unproven effects, added another layer of uncertainty in currency markets, thus further heightening volatility.

Falling commodity prices, particularly oil, also contributed to FX volatility. Since most commodities are priced in USD, consequences for currencies of commodity exporting countries have been severe. The Russian, Canadian, Brazilian, Australian, and South African currencies fell precipitously. This, plus slowing economic growth in these countries, has led to capital flight and additional pressure on their currencies. Slowing GDP growth in China added uncertainty about future demand, commodity prices, and currency valuation. All this uncertainty about growth and exchange rates, coupled with conflict and political turmoil in Syria, Iraq, and the Ukraine, as well as political unrest in Argentina, Brazil, and Venezuela, added to volatility in the FX market.

2014 became a year of global political uncertainty, spurring a rise in the safe haven currencies, the USD and Swiss Franc. The yen, traditionally also a safe haven currency, for reasons discussed previously, was not in 2015. However in 2016 it assumed that role again, rising significantly. The European sovereign debt crisis reemerged with a new anti-austerity government in Greece. The uncertain future of the euro contributed to its depreciation. Despite agreements between the IMF, EU, $\mathrm{ECB}$, and the Greek government, Europe's sovereign debt crisis is far from resolved. In addition, the refugee crisis and British exit from the EU created greater economic uncertainty across the Eurozone. Donald Trump's election as President of the US in November 2016, and possible implementation of his protectionist and nationalist policies, will likely maintain high levels of volatility in currency markets for some time.

Currency has become a separate asset class for many investors in recent years, increasing trading volume (Pojarliev \& Levich, 2015). Daily volume, estimated at $\$ 5$ trillion a day in 2016 by the BIS, is up about $25 \%$ since 2010 . Once the USD's ascent was established, it was perpetuated by traders including hedge funds (Menkhoff et al., 2012a). The FX recent history seems to confirm that momentum and trend-following have become major strategies shaping currency price paths. Value traders predicting the fall of the euro and yen against the USD, carry traders buying high interest rate currencies and selling low interest rate ones, and retail currency traders tend to be short-term traders and trend followers whose strategies require price movement to be successful. Increased trading by these players, slow economic growth, and political instability are major causes of heightened volatility in global currency markets (Spronk et al., 2013). The high level of uncertainty in the global economy is the major driving force behind the volatility in the FX market.

\section{How Does Currency Volatility Affect International Business?}

Few decisions in multinational firms are not affected by currency values and expected changes in those values. These even impact firm competitiveness. A strong currency hinders exports and benefits imports, while a weak currency does the opposite. In a strong currency country exporters will be in a less competitive position, while importers will benefit. Foreign investment decisions, both portfolio and direct, are strongly impacted by currency volatility in the long and short run. Financial firms and non-financial firms with substantial shortterm investments find that currency effects magnify returns and losses on their portfolios. Direct investment into facilities and mergers and acquisitions may be discouraged by currency volatility as firms defer FDI until more clarity in exchange rate paths is perceived (UNCTAD, 2014). The concurrent political and economic instability causing much of the currency volatility may also cause hesitation in investment decisions.

Currency volatility affects sourcing decisions as well. Countries with weak currencies become more attractive as manufacturing or sourcing sites. In very price-elastic industries such as clothing and shoe manufacture, weaker currencies in most Southeast Asia countries, coupled with already low labor costs, have made them more attractive sourcing locations. Mexico's weak currency attracts both FDI in the auto and aviation industries 
and contract manufacture in other industries. Firms in countries with strong currencies seek productivity enhancement with automation and improved work methods to offset their currency disadvantage. This includes China, where the RMB has strengthened in recent years, despite depreciating lately.

The strong USD has taken a bite out of US multinationals' earnings. The value of their European, Japanese, and other foreign source income in countries with weaker currencies has been reduced, in some cases 10-20\%. Even if these losses are not realized until profits are repatriated, they still impact reported results, which negatively affect share prices, management bonuses, and performance evaluation. Through translation exposure, MNEs also experience reductions in global equity on their balance sheets when consolidating financial statements of foreign subsidiaries.

Finance groups in global firms are responsible for mitigating short-term effects through risk management and hedging activities and for the long-term consequences of managing investments and financing for foreign subsidiaries as well as the parent firm. Many developed and emerging market firms have sought financing in USD because the US has relatively low interest rates. A weak local currency increases the burden of paying back foreign currency debt. At the same time investors have pulled back from emerging market corporate debt due to concerns about slowing economic growth and increased default risk. Firms with USD revenues, such as exporters, are somewhat insulated, but many firms do not have such cover.

Global firms also must confront effects of currency volatility on transfer prices, cash flows, and working capital positioning. Transfer prices among subsidiaries will fluctuate along with the currencies involved and affect each subsidiary's revenues and costs. It will also influence where working capital accumulates and is depleted affecting subsidiaries' daily operations. Cash held by subsidiaries in weak currency countries will lose value in terms of the firm's home currency. Additionally MNEs in weak currency countries will show translation losses when consolidating financial statements of those subsidiaries. There may be tax consequences as the income of subsidiaries is altered by currency changes affecting costs and revenue.

\section{How Can Firms Manage Currency Volatility?}

Exchange rate volatility presents not only risks but opportunities. Firms that respond more quickly and effectively to this challenge will gain competitiveness against rivals. Responses, just like consequences, are both strategic and operational and span a range of functions and decisions in MNEs. Strategically the most important decisions will involve which products and services to offer in which markets. The ideal strategy is to export from weak currency countries to strong ones and to source products and materials in weak currency countries. Also a firm based in a strong currency country can position itself in less price-elastic product lines or in less price-sensitive markets. This generally implies brand name, higher technology products and services sold in more developed countries. Another response, short of changing the product lineup, is to shift production and sourcing to countries with weaker currencies. This could be a faster response to current conditions for firms that outsource these activities, but may not be as effective in the long run to mitigate currency volatility as strategies emphasizing changing products and services and matching costs and revenues in key currencies.

Marketing decisions can also play a critical role. The amount and type of advertising and promotion can be altered to respond to lower or higher competitiveness in a particular market due to currency fluctuations. For example, selling into countries with weakened currencies can be mitigated to some extent by expanded advertising and promotional methods. The firm might also choose to forego price increases in a weak local currency to maintain market share. On the other hand, a firm exporting from a weak currency country may choose to lower foreign currency prices to gain market share.

Production and sourcing decisions are also critical in dealing with currency volatility. Sourcing flexibility is limited for some firms because of existing capital investment and proprietary technology. But most firms have at least some sourcing flexibility. The trends towards contract manufacturing and outsourcing in developed countries enable a firm to shift supply sources. For some products sourcing can be fairly quickly shifted (e.g., clothing and shoe manufacturing) while for others, even if possible, the lead time to find, vet, and develop suppliers can be fairly long. Short of shifting production locales, a firm could source some materials in lower cost countries where exchange rates have fallen. The best long term solution for mitigating exchange rate exposure is producing where you sell, which matches revenues and costs in the same currency.

The firm's finance group should be heavily involved in formulating strategic and operational decisions that benefit from or mitigate currency exposure. Tools and methods, such as standard hedging tools (forwards, futures, options and swaps), shifting cash within the global corporate network, and working capital management (e.g., netting, leads and lags on payments, transfer pricing, cash centralization) can help meet the challenge of exchange rate volatility. These short-run techniques can mitigate currency volatility, but again longer-term measures such as long-term financing in currencies with substantial revenues (i.e., matching), cross-currency swaps to realign the current financial structure, and centralizing management of corporate cash flows, should also be implemented to position the firm for an extended period of unpredictable long-term currency movements. 
Table 1 summarizes major strategic and operational hedges for foreign exchange volatility. Different hedges are separated by whether they are primarily short-term or long-term. Most hedges can be used in response to either an appreciating or a depreciating currency, but of course they would be employed differently (e.g. reduce exchange rate pass-through in a depreciating currency country and increase it in an appreciating one). Some longer-term hedges can be effective for either scenario by mitigating effects of a currency movement in either direction (e.g., match revenues and costs by currency).

\section{Conclusions and a Look Ahead}

Is the current turbulence in currency markets a short-lived phenomenon, or does it portend an extended period of high volatility? Of course, no one can be certain whether FX will revert to relative stability or continue on the more turbulent path of the last several years. The answer is very important to global firms as they make their strategic and operational decisions.

There are reasons to expect an extended period of currency volatility. Slow growth in the major developed economies suggests that monetary stimulus programs of the Bank of Japan and the ECB will continue for some time resulting in low and, even negative, interest rates. The U.S. Federal Reserve is expected to continue raising interest rates in 2017 and 2018. Anticipation of diverging interest rates has been a major driver of recent currency volatility, and exchange rate volatility will likely remain until more certainty about interest rates is achieved. Political instability in the Middle East, Latin America, Ukraine, and Africa also contribute to volatility, and these conflicts are far from resolved. A third contributor to exchange rate volatility has been European factors: the Greek debt crisis, Brexit, the refugee crisis, and the rise of populism. How these issues will play out is far from clear and will probably not be resolved anytime soon. The election of Donald Trump as president of the U.S. and ambiguity about his economic and political policies creates another layer of uncertainty. Although global commodity prices, especially oil, are difficult to forecast, they will significantly affect many firms' costs and revenues. Since most commodities are priced in USD, USD volatility adds another layer of risk in pricing commodities in a local currency. Uncertainty breeds volatility, and right now uncertainties affecting currency markets are likely to continue for some time with no clear resolutions in sight.

MNE managers should plan for an extended period of FX volatility and, as much as possible, insulate their firms from it. Attempting to forecast currency movements is extremely difficult, especially in the short run, and many economists consider exchange rates essentially a random walk (Rogoff, 2009). The most effective way to insulate a firm from currency movements is to match cash flows in the major currencies by selecting markets and products on the revenue side and production locations and sourcing decisions on the cost side. As an additional overlay, financing in currencies of major revenue streams can be an effective hedge (e.g., euro revenues can be matched to euro financing with $€$-denominated debt). For shorter-term hedging conventional instruments of FX forwards, futures, options, and swaps can be utilized. Beyond insulation and hedging, however, firms can use currency movements as an opportune time to secure competitive advantage. By exporting to countries with strong currencies and sourcing in countries with weak curren-

\section{Table 1: Hedging Strategies for Currency Volatility}

Short Run

Marketing

Production

Finance

Strategy swaps)
Adjust advertising \& promotion

Alter prices/exchange rate pass-through

Change product mix

Change sourcing countries

Increase outsourcing

Hedging (forwards, futures, options,

Adapt working capital management

Increase exports to strong currency countries and imports from weak
Long Run

Change target markets

Retool product lines

Change facility locations

Improve productivity

Increase automation

Match financing to revenue by currency

Currency swaps

Centralization of cash mgmt.

Match revenues with costs by currency 
cies, MNEs can gain advantage over less fleet competitors. This requires flexibility in both marketing and supply chains, which is a desirable quality in any MNE, but particularly in these times of large currency movements. With the proper strategies, currency volatility can be an opportunity as well as a threat to MNE's. This requires planning and positioning as discussed in this article.

\section{References}

Menkhoff, L., Sarno, L., Schmeling, M., \& Schrimpf, A. 2012a. Currency momentum strategies. Journal of Financial Economics, 106: 660684.

Menkhoff, L., Sarno, L., Schmeling, M., \& Schrimpf, A. 2012b. Carry Trades and Global Foreign Exchange Volatility. The Journal of Finance, 67(2): 681-718.

Pojarliev, M., \& Levich, R. 2015. A New Look at Currency Investing. Charlottesville, VA: CFA Institute.

Rogoff, K. 1996, The purchasing power parity puzzle. Journal of Economic Literature, 34(2): 647-668.

Rogoff, K. 2009. Exchange rate in the modern era: what do we really know? Review of World Economy, 145: 1-12.

Spronk, R., Verschoor, W., \& Zwinkels, R. 2013. Carry trade and foreign exchange rate puzzles. European Economic Review, 60: 17-31.

UNCTAD. 2014. World Investment Report 2014. Geneva: UNCTAD.

Robert N. Mefford (mefford@usfca.edu) is a Professor of Finance at the School of Management at the University of San Francisco. He has published more than 30 articles on a variety of topics in international business, finance, and operations and supply chain management. He received his BS degree from the University of Southern California, his MBA from UCLA, and an MA in Economics and a PhD in International Business from UC Berkeley. 